\title{
Culture-related decision conflicts in the translation process
}

\author{
Terje Loogus \\ Department of Semiotics, University of Tartu \\ Jakobi 2, 51014 Tartu, Estonia \\ e-mail: terje.loogus@ut.ee
}

\begin{abstract}
Translators as members of a certain culture, generally that of the target culture, base their translation-relevant decisions on their own culture, while the decisions are motivated by the (alien) source culture. In the translation process, cultural differences may lead to various decision-making conflicts and the translator has to find a compromise between the author of the source text, the target recipient and finally, of course, the translator him/herself. In this article, proceeding from functionalist approaches to translation, the discussion focuses on the decision conflicts related to translating culturespecific elements. Culture-related decision conflicts, as considered here, refer to the translator's inner indecision with reference to his/her goals, interests, values, beliefs, methodological approach, or any consequences thereof, attributable to the different cultural embeddings of the source text and the target text. In general, decision conflicts are perceived as subjective translation problems. The translator has to be able to constantly act between separate perspectives, continuously see things from different viewpoints. The conflicts arise when the translator attempts to bring together two incongruent cultures without prejudice to any of the parties involved in the process. Acting within the interface of two different cultures, bearing in mind the interests of several participants, is what makes translation-relevant decisions a highly complex matter.
\end{abstract}

\section{Translation and culture}

In translation studies, culture became an object of study in the 1970s, when, owing to the pragmatic turn, researchers started to pay more attention to the function of verbal expression and correlate linguistic forms with aspects of the lifeworld. As a result of the "cultural turn" (Lefevere, Bassnett 1990: 1) or even "cultural turns" (Bachmann-Medick 2006), the cultural embedding of communication gained momentum in the 1980s. Accordingly, translation is not 
regarded as just a simple transfer from one language into another, or from a source text into a target text, but also as a transfer between cultures (see Vermeer 1986). Therefore, it is only natural that, before any linguistic expression is formulated, the cultural context needs to be considered.

The word "culture" can be interpreted in different ways and from different points of view. According to Michael Agar (2006: 2), "culture is one of the most widely (mis) used and contentious concepts in the contemporary vocabulary". In the humanities, culture is normally viewed either from a socialtheoretical perspective, which considers culture in connection with social order, social changes or identity of societies, or from the perspective of action theory or communication theory, according to which culture allows orientation in the form of background expectation and cognitive patterns (Loenhoff 1992: 114). Accordingly, the notion of culture relevant to translation studies can be looked at on three different levels, while the borders between the levels often overlap:

(1) The material dimension of culture, i.e. culture as an entity of artefacts which become bearers of sense and meaning.

(2) The mental dimension, i.e. culture as explanatory and activity-oriented knowledge systems, cognitive patterns and culture-specific competence systems. By reference to real existing problems, culture functions as a meaning framework and a pattern of interpretation and thus allows the building of collective orientations.

(3) The pragmatic dimension, i.e. culture as concrete actions and communications which produce, reproduce and employ culture. (Loenhoff 1992: $139,144)$

A traditional definition of culture, widely discussed in translation studies up to now, is based on a broad anthropological sense of the term, defined by the American ethnologist Ward H. Goodenough:

As I see it, a society's culture consists of whatever it is one has to know or believe in order to operate in a manner acceptable to its members, and do so in any role that they accept for any one of themselves. Culture [...] must consist of the end product of learning: knowledge, in a most general, if relative, sense of the term. By this definition, we should note that culture is not a material phenomenon; it does not consist of things, people, behavior, or emotions. It is rather an organization of these things. It is the forms of things that people have in mind, their models for perceiving, relating, and otherwise interpreting them. (Goodenough 1964: 36) 
This definition - in a slightly modified form - has been introduced into the study of intercultural communication by Heinz Göhring (1978) in Germany and has served as a general starting point for functionalist approaches to translation (Nord 2001: 24). Culture is considered here as an orientation system which is typical for groups or societies. Culture implies common shared knowledge, which serves as a collection of recipes for problem solving, and enables people to behave and act in a culturally accepted manner and in accordance with rules and regulations. According to this definition, different cultures are more or less delimited, often ethnically defined social units whose members share common background knowledge, which through norms and conventions determines their common action, and which compared to other cultures appears as different ${ }^{1}$ (see Altmayer 2002: 6). However, Göhring (1998: 112) stresses the fact that in intercultural communication individuals are free either to comply with the behaviour patterns accepted in the other culture or to bear the consequences of behaviour that is inconsistent with cultural expectations.

Recent years have brought along a trend that deviates from perceiving cultures as distinct and homogenous units, and which stresses their complexity and complementarity instead of differences between cultures. The new notion of culture is also revealed in the concept of transculturality, which aims at phenomena common in different cultures. According to Welsch (1999: 198), transculturality is a consequence "of the inner differentiation and complexity of modern cultures". Welsch (ibid.) emphasizes that transculturality does not only apply to the macrocultural level, but also to the individual's micro-level. In the world of globalization, for many people multiple cultural connections are instrumental for the formation of their cultural identity. This also applies to translators who often have multiple enculturation.

As noted before, translation involves mediation between different languages as well as cultures. Language is an intrinsic part of culture and, in order to emphasize the interdependence of language and culture, Agar (1994: 60) has introduced the notion of "languaculture". According to him, the culture boundary is marked by "rich points" (Agar 1994: 100), which are differences in behaviour that cause culture conflicts or communication problems between

1 See Claus Altmayer's article "Kulturelle Deutungsmuster in Texten. Prinzipien und Verfahren einer kulturwissenschaftlichen Textanalyse im Fach Deutsch als Fremdsprache" (Altmayer 2002: 6), in Zeitschrift für Interkulturellen Fremdsprachenunterricht [Online], 6(3), available at http://zif.spz.tu-darmstadt.de/jg-06-3/beitrag/deutungsmuster.htm. 
two communities in contact. It needs to be stressed, however, that rich points or culture-specific differences are always relative, e.g. the contact of Estonian and English reveals rich points that a contact of Estonian and Finnish might not reveal. Cultural differences become visible only when they appear with reference to an outsider who comes into contact with the "other" culture, and they always depend on the cultural background of the newcomer (Agar 2006: 5). Therefore, it is important to stress, as Agar (ibid.) does, that "the shape that culture takes depends on the of whom/for whom boundary". Not all boundaries generate the same amount of rich points.

\section{Translating and decision-making process}

Since the 1980s, translation scholars have also been paying more attention to mental processes and psycholinguistic issues. The aim of the descriptive process-oriented research into translation is to find out "what goes on in the translator's head" (Krings 1986), i.e. how he/she translates and which decisions he/she makes while translating (Lörscher 1992: 159).

Translation is a complex decision-making process, involving certain problem-solving activities and comprising reception, understanding and interpreting of the source text, as well as creating a target text which is consistent with the author's intentions and considers the needs of possible recipients. A decision problem occurs when the translator is faced with an issue which demands some form of choice. To some extent, the translator's discretion may be restricted since his/her decisions are always rooted in the existing source text, but this does not diminish the translator's liability for the consequences of the decisions made.

Based on the fundamental process-oriented model of descriptive decision theory (see Pfohl, Braun 1981: 102), five stages may be distinguished in the process of taking translation decisions:

(1) identifying the problem;

(2) gathering information;

(3) finding possible options for resolving the problem;

(4) evaluating the available options;

(5) selecting the best option, and resolving the problem. (See Loogus 2008a: 170-173) 
Decisions made in the course of translating are part of a complex informationprocessing procedure, which includes cognitive as well as intuitive processes. Solving different translation problems involves making decisions of diverse cognitive complexity. Some decisions are easy to make and do not require considerable cognitive effort (routine decisions); others, in contrast, demand thorough information gathering and processing (decisions directed at problem-solving). Translation entails both "sure" (Mag 1990: 7; see also Wilss 2005: 9) and "unsure" (see Jungermann et al. 2005: 143) decisions. The translator's indecisiveness may derive from a poor command of the language, from inadequate knowledge of cultural aspects or of the subject matter, and also from a lack of pragmatic information concerning the translation brief.

Decision-making process is a multi-stage, goal-oriented, calculating and conflict-conscious process. This process is not always easy; it often involves the risk of making a "wrong" decision. As any choice contains an element of risk, decisions often involve a feeling of uncertainty. A decision conflict occurs when the translator is faced with a situation where he/she has to make a choice, but for some reason or other - is not able to do this.

\section{Culture-related decision conflicts}

The translator as a mediator between two cultural groups is at the centre of transfer between cultures that, due to language barriers, could not have come into contact with each other. It is intrinsic to translation that the parties between whom the translator acts as a mediator - both languages and cultures - differ from each other. The incongruity of cultures may derive from different linguistic systems or different extra-linguistic domains or also from different natural environments (Frank, Schultze 1988: 96). In order to bring the two parties into contact, the translator has to go through a multi-step decisionmaking process. That means that the translator, in his/her double role as a recipient of the source text and the producer of the target text, makes complex decisions which often involve internal conflicts. As used here, culture-related decision conflicts mean the translator's inner indecision in relation to his/her goals, values, beliefs and methodological approach, or any consequences arising from different cultural embeddings of the source text and the target text.

The reasons for the emergence of culture-related decision conflicts can be described as follows (see also Loogus 2008b: $234 \mathrm{ff}$.). In today's globalizing world, most people identify themselves in more than one way, i.e. their lives are 
ordered through different identities. The same applies to translators who, due to their profession, come into contact with at least two languages and cultures, are ideally encultured in both cultures and, accordingly, have multiple affiliations (Turk 1996: 15). Translating means comparing cultures. Translators interpret source-culture phenomena in the light of their own knowledge of this culture, which means that there can be no neutral standpoint for comparison (Nord 2001: 34). Everything they perceive as being different from their own culture depends on their culture of primary enculturation and on their previous knowledge of the other culture. The double enculturation or multiple affiliations mentioned may lead to decision-making conflicts while translating, if there is an internal disparity between ideas, values, motives or goals. As with many other action situations, translation involves a clash between various perceptions and viewpoints that attempt to gain power.

The translator who brings two cultures together is in a double role: on the one hand, the translator is a recipient of a text - usually a foreign language text - that he/she receives from the perspective of his/her own culture and the text-world of which he/she tries to fit into his/her real world; on the other hand, the translator is a producer of the target text. At the reception stage, the two opposites meet: the author of the text and the translator, each of them embedded in their respective culture. In the translation process, the author of the text appears as a passive participant; the translator, in contrast, takes on an active role and has to negotiate solutions. The author has compiled a text bearing in mind particular goals and specific addressees who, as may be assumed, at least partly share the author's pre-knowledge, certain collective background knowledge that enables the addressees to understand the text as it has been intended. The author does not have to be explicit about everything; many things can be omitted since he/she may presuppose that the text is more or less consistent with the presupposed understandings of the addressees. What the author as a representative of the source culture expresses in the text is certainly influenced by this culture. The translator receives the source text on the basis of his/her own culture, while being aware of and taking into account cross-cultural differences. In a way, the translator is responsible to those who depend on the service provided by him/her; therefore, the translator has to make efforts so as to receive the text in line with the author's intentions. That is how the translator is a meeting point of two perspectives - that of both the source culture and the translator's own culture. 
Apart from being a receiver of the source text, the translator is also a producer who transfers the text created in the source culture into the target culture. In this role, the translator acts as a representative of the source-culture author and takes care that the latter's intentions are expressed in the target text. Translations as target texts maintaining a relationship with a given source text (Nord 1989: 102) are also produced for a certain purpose and particular addressees, except that the target text addressees usually do not belong to the same cultural and linguistic community as the source text addressees. In most cases, the target text addressees lack the background knowledge that the author of the source text has expected the addressees to have. Instead, the target text addressees may, owing to their different cultural background, have completely different expectations of a given text. That is where the translator's role as an active cultural intermediary begins, since the translator does not act in his/her own interests but for the benefit of the target addressees, whose conditions of reception the translator has to consider. The translator has to pave the way for the target addressees' prerequisites of understanding, because the purpose of the target text may be achieved only if the text corresponds with the target addressees' expectations. Consequently, the source text needs to be transferred to the target culture, taking into account the requirements of the target language and target-cultural prerequisites of understanding. Depending on cultural differences, the translator has to alter the information contained in the source text so that it can be interpreted in accordance with the intentions of the source text author. Jiř́ Levý (1969: 72) describes a translation as a mixed, hybrid composition because it comprises both the purport and formal shape of the original, as well as the whole system of characteristic features of a given language that have been added to the text by the translator. The two layers brought together in a translation are conflicting and can be negotiated only as a compromise between the meaning of a certain source text element and reproduction options and conditions of the specific text element mentioned.

Clashes of two cultures may lead to the translator's internal conflict between two different perspectives. As a rule, the translator feels at ease in both cultures and can position himself/herself in both perspectives, but, while translating, still has to choose between them. The conflicts arise when the perspectives that the translator tries to bring together cannot be consolidated without prejudice against one of the two sides. Acting on the interface of two different cultures, bearing in mind the interests of several participants - the author of the source-culture text as well as the target-culture recipients and, last 
but not least, the commissioner of the text - makes translation-relevant decisions a highly complex matter. The translator has to be able to act between different perspectives and constantly shift between different viewpoints. Changing the perspectives and looking at the same incident from different standpoints may cause the emergence of internal decision conflicts that are connected with culture-specific translating.

\section{Categories of intraindividual decision conflicts}

Intraindividual conflicts occur in the translator's mind and cannot be observed from the outside. Nevertheless, by analyzing translations it is possible to obtain insights into potential conflicts having arisen in the translation process. Translation always implies solutions to problems, and frequently translations reveal whether the solutions have been effective. Based on the typology of conflicts widely used in decision theory (see Pfohl, Braun 1981: 437), four types of decision conflicts may be distinguished in connection with translation: conflicts of purpose, values, beliefs and methodology (see also Loogus 2008b: $238 \mathrm{ff}$.).

\subsection{Conflicts of purpose}

By "conflicts of purpose", the translator's internal state of imbalance in connection with the set objectives is meant. These conflicts relate to texts, their function and mutual relationship, and they influence the overall strategy chosen by the translator. At the heart of the translator's considerations is the question: what does the translator seek to achieve with the translation? In culture-specific translation, the translator is drawn between two functional objectives: on the one hand, he/she wants to inform the readers of the source culture and its distinctive features. As a representative of the source culture in the target-culture environment, the translator's goal is to maintain the sourcecultural specificity to an extent which enables the readers to share in the source culture as much as possible. The translator's purpose is to provide the addressees with profound knowledge of the other culture and thus enrich the target culture by making available new notions, concepts and worldviews. On the other hand, the translator attempts to produce a text which achieves its purpose in the target culture. For a target text to have a similar effect on target addressees as the original text has on the source culture readers, the translator 
has to take account of the recipients' prerequisites of understanding and match the contents of the source-cultural text with the conditions of reception. The translator should not overburden his/her readers with the specifics and detailed circumstances of the other culture. Observing this purpose may lead to the elimination of the specificity of the source culture, since an attempt to produce a genuine target-cultural text also implies a neutral presentation which is not source-culture oriented. It is in the nature of conflicts that the two objectives described cannot be equally achieved. Quite the contrary - fulfilling one of the objectives, for example, providing the target culture with new notions, inevitably means abandoning the other purpose, i.e. adapting the sourcecultural particularity to target-cultural conditions of reception. Solving the conflicts of purpose depends on the choice made between two alternative types of translation - domesticating or foreignizing translation.

\subsection{Conflicts of values}

Conflicts of purpose are directly related to conflicts of values. Value conflicts are meant to include all intraindividual conflicts relating to principles that involve translation norms, as well as the translator's personal values or moral norms. Similar to conflicts of purpose, value conflicts occupy two opposing positions in a translator. While the conflicts of purpose are caused by the translator's inability to choose between different functional objectives, the conflicts of values also include an ethical dimension: there is a conflict between the translator's liability to the source text and to the target addressees. Accordingly, value conflicts include all tense situations which, one way or another, derive from showing more respect either towards the original text and its author or towards the targetculture addressees. The translator has to decide in favour of one side, because he/she cannot serve two masters at the same time.

In order to illustrate a conflict possibly caused by moral norms, an extract from the novel Ma armastasin venelast (I Loved a Russian) by the Estonian writer Maimu Berg (1) and its translation into German (1a) (translated by Irja Grönholm) might be considered. There is a passage in the novel which describes a social gathering of writers of different nationalities, where a Romanian writer is teaching the others a Romanian Christmas song: 
(1) Laulus kordub sõna „hui“, vene keele oskajaid [... ] ajab hirmsasti naerma, kuidas kõik Lääne omad püüdlikult seda sõna kordavad ja laulavad. (Berg 2004: 123)

[In the song, the word "hui" is repeated; it gives those who know Russian [... a good laugh at how all Westerners carefully repeat and sing the word.] (My translation - T. L.)

(1a) Im Lied wiederholt sich das Wort „hui“; diejenigen, die Russisch können $[\ldots]$ müssen schrecklich lachen, wie all die Westler dieses Wort - „Hure” - voll Ernst und Eifer singen. (Berg (Grönholm) 1998: 215)

[In the song, the word "hui" is repeated; it gives those who know Russian [...] a good laugh at how all Westerners seriously and enthusiastically sing the word "whore".] (My translation - T. L.)

In German, the Russian obscene word denoting male genitals has been replaced with the word Hure (whore), which does not sound so embarrassing, yet, even though in a less pronounced manner, still communicates the comedy of the situation. In the original Estonian text, the word in Russian has not been translated because the author obviously assumes that the readers can understand it. The translator, however, cannot presuppose that the target readers will have such a "thorough" knowledge of Russian and, therefore, has to find a translation equivalent. She has replaced the obscene word with a more moderate equivalent. We cannot be sure why the translator has come to this solution; we can only assume that the translator's choice may have been influenced by the linguistic or ethical norms of the target culture, or by the translator's or the editor's personal moral norms.

The same novel has also been translated into Finnish (1998, by Hannu Oittinen) and Swedish (1997, by Enel Melberg) and in both translations, the word in Russian has been neither translated nor explained. So we can assume that most Finnish and Swedish readers would not understand the comedy of the situation. Neglecting a problem can also be a possible solution for a decision conflict of values. 


\subsection{Conflicts of beliefs}

Conflicts of beliefs relate to the translator's internal conflicts concerning factual information about reality. The borderline between value conflicts and the conflicts of beliefs is very narrow, because every belief simultaneously also reflects the individual's moral concepts. Conflicts of beliefs, however, centre not on the ethical considerations of the translator, but the translator's personal knowledge-based beliefs, the truth claim of which is in conflict with that of the source-text author or the commissioner. A conflict may arise when the commissioner insists on getting a translation that closely follows the original, whereas the translator's experience has shown that a translation produced this way would not work. Advertisements, for example, are compiled in view of specific source-cultural conditions and cannot be transferred into the target culture as word-for-word translations. Conflicts of beliefs may also be caused by factual mistakes in the source text that the translator has detected on account of his/her knowledge; however, he/she cannot be sure whether he/she may correct them or not. These conflicts are not necessarily provoked by cultural differences; frequently, this is a matter of specialist knowledge. On the borderline between the conflicts of values and conflicts of beliefs, there are instances when the translator's beliefs clash with the information contained in the text.

Seeking a compromise over a conflict of beliefs is harder, since an individual's beliefs always rest on his/her personal convictions about the truth of certain propositions or circumstances and are relatively rigid as regards changes. Due to diverse enculturation and socially or individually conditioned truth criteria, people have different experience of the world around them. Finding ourselves confronted with opposite views, we frequently try to enforce our own personal belief as the truth, unless it has been disproved by some arguments or evidence.

Another extract (2) from the novel mentioned above $M a$ armastasin venelast (I Loved a Russian) by Maimu Berg might serve as an example of a possible conflict of beliefs. The main character's reflections in the original text are communicated as follows:

(2) Kuskil pole elu nii kole kui Venemaal. Kuskil ei ole inimelu hind nii madal. Kuskil ei ole uuendused ja muutused, kõik see, mida vaba maailm on harjunud pidama demokraatiaks, nii võimatud. (Berg 2004: 147) 
[Nowhere is life as awful as in Russia. Nowhere is human life worth so little. Nowhere are renewals or changes, everything that the free world long regards as democracy, so impossible.] (My translation - T. L.)

(2a) [.... Nirgendwo sind Erneuerungen und Veränderungen, all das, was die freie Welt Demokratie nennt, so unmöglich wie in Rußland. (Berg (Grönholm) 1998: 252)

[Nowhere are renewals and changes, everything that the free world calls democracy, as impossible as in Russia.] (My translation - T. L.)

In this case, the translator has omitted two first sentences. The decision may have been conditioned by her moral motives or beliefs. Also, the author's and the translator's different cultural backgrounds may have been behind that: the two women have been brought up in different countries, and therefore their views on the events happening in the world are different. What people consider to be true does not depend only on their knowledge, but also on the sociopolitical and cultural situation. We cannot completely ignore the possibility that the translator omitted these sentences just by mistake, but there are some other omissions of similar nature in the German translation (e.g., on page 141), which may suggest that this was the translator's (or the editor's) deliberate decision. In the Finnish and Swedish translations, however, all the sentences have been translated. The translators probably did not consider it necessary to leave anything out.

\subsection{Conflicts of methodology}

In some respect, the above-mentioned decisions relating to purpose, values and beliefs may also be called purely intellectual decisions (Ladmiral 1999: 164), because they are concerned with fundamental questions and principles of translation-related decisions. The decisions discussed provide a basis for the so-called technical choices, i.e. decisions concerning the methodology of handling the culture-specific content of different texts. In translation, decision conflicts are always ultimately solved by making methodological decisions. Such methodological decision conflicts include conflicts which arise from translating individual textual elements on the text level. On the one hand, they comprise decisions on the type of translation - either domesticating or foreignizing translation. On the other hand, they concern the use of various translation methods on the micro-level of the text, i.e. on the level of words and 
sentences, and imply choosing between alternatives, e.g. "word-for-word" or "free" translation; "explication" or "implication", etc. These are the most common conflicts that the translator needs to resolve - they relate to the strategies chosen by the translator while solving the problem of foreignness of a text as a whole or translating particular culture-specific textual elements.

\section{Conclusion}

Translation as mediation between cultures inevitably implies comparing different cultures. For the translation process to run smoothly, the translator has to be aware of differences between his/her own and the other culture, i.e. an excellent cultural competence on the part of the translator is essential. Unawareness may result in internal conflicts, as well as leading to situations where culture-specific aspects are not recognized or cultural differences become cultural barriers (Vermeer 1989: 37).

Culture-specific decision-conflicts arise from different cultural embeddings of the source text and that of the target text and their causes can be summarized as follows:

- the translator's double role as the recipient of the source text and the producer of the target text in the area of conflict of two cultural perspectives;

- the translator's double liability to the source-text author (or to the commissioner) and to the target addressees;

- disagreement between the purpose and the possibilities of realizing the purpose;

- cultural differences, e.g. different conditions of understanding due to different cultural embeddings, different linguistic restrictions and textual conventions, different norms of behaviour in similar situations, etc.;

- incomplete information available to the translator; and

- last but not least, the complexity of the translation process.

Similarly to many other classifications, there is no clear borderline between various types of conflicts. Several decision conflicts may occur simultaneously and condition one another. The conflicts of purpose relate to the translator's overall objectives and the question of what he/she wants to achieve with the translation. The translator's moral decisions, which concern the responsibility 
to other participants, are closely connected with that and may in turn result in value conflicts. The conflicts of beliefs are associated with factual information about reality. Decisions concerning the purpose, values and beliefs finally extend to the methodological decisions on translating particular textual elements and these, in turn, may lead to conflicts between translation methods.

To conclude, conflicts can be resolved if they are recognized in good time. Only after the translator has become aware of a problem, is he/she able to handle it and turn the conflict into a constructive force. ${ }^{2}$

\section{References}

Agar, Michael 1994. Language Shock: Understanding the Culture of Conversation. New York: William Morrow.

- 2006. Culture: Can you take it anywhere? International Journal of Qualitative Methods, $5(2), 1-16$.

Bachmann-Medick, Doris 2006. Cultural Turns. Neuorientierungen in den Kulturwissenschaften. Hamburg: Rowohlts Enzyklopädie.

Berg, Maimu 2004. Ma armastasin venelast. Tallinn: Tänapäev.

- 1998. Ich liebte einen Russen: zur Erinnerung an die schneereichen Winter der Kindheit. Aus dem Estnischen von Irja Grönholm. Blieskastel: Gollenstein.

Frank, Armin Paul; Schultze, Brigitte 1988. Normen in historisch-deskriptiven Übersetzungsstudien. In: Kittel, Harald (ed.), Die literarische Übersetzung: Stand und Perspektiven ihrer Erforschung. Berlin: Erich Schmidt, 96-121.

Göhring, Heinz 1978. Interkulturelle Kommunikation: Die Überwindung der Trennung von Fremdsprachen- und Landeskundeunterricht durch einen integrierten Fremdverhaltensunterricht. In: Kühlwein, W., Raasch, A. (eds.), Kongreßberichte der 8. Jahrestagung der Gesellschaft für Angewandte Linguistik GAL e. V. Mainz 1977. Stuttgart: Hochschulverlag, 9-14.

- 1998. Interkulturelle Kommunikation. In: Snell-Hornby, Mary; Hönig, Hans G.; Kussmaul, Paul; Schmitt, Peter A. (eds.), Handbuch Translation. Tübingen: Stauffenburg Verlag, 112-115.

Goodenough, Ward H. 1964. Cultural anthropology and linguistics. In: Hymes, Dell (ed.), Language in Culture and Society. New York: Harper and Row, 36-39.

Jungermann, Helmut; Pfister, Hans-Rüdiger; Fischer, Katrin 2005. Die Psychologie der Entscheidung. Eine Einführung. Heidelberg: Elsevier, Spektrum.

2 Acknowledgement: The author thanks the European Social Fund and Estonian Science Foundation for support (Mobilitas Grant No. MJD70). 
Krings, Hans P. 1986. Was in den Köpfen von Übersetzern vorgeht. Eine empirische Untersuchung zur Struktur des Übersetzungsprozesses an fortgeschrittenen Französischlernern. Tübingen: Narr.

Ladmiral, Jean-René 1999. Die Übersetzung: von klassischen Texten? In: Hess, Remi; Wulf, Christoph (eds.), Grenzgänge. Über den Umgang mit dem Eigenen und dem Fremden. Frankfurt/Main: Campus Verlag, 162-187.

Lefevere, André; Bassnett, Susan (1990). Introduction: Proust's grandmother and the thousand and one nights: The 'cultural turn' in translation studies. In: Bassnett, Susan; Lefevere, André (eds.), Translation, History and Culture. London: Pinter, 1-13.

Levý, Jiř́ 1969. Die literarische Übersetzung. Theorie einer Kunstgattung. Frankfurt am Main: Athenäum Verlag.

Loenhoff, Jens 1992. Interkulturelle Verständigung. Zum Problem grenzüberschreitender Kommunikation. Opladen: Leske + Budrich.

Lörscher, Wolfgang 1992. Process-oriented research into translation and implications for translation teaching. TTR: traduction, terminologie, rédaction, 5(1): 145-161.

Loogus, Terje 2008a. Translation als komplexer, zielgerichteter und problemlösungsorientierter Entscheidungsprozess. Triangulum. Germanistisches Jahrbuch 2007 für Estland, Lettland und Litauen, 13: 163-181.

- 2008b. Kultur im Spannungsfeld translatorischer Entscheidungen: Probleme und Konflikte. Berlin: Saxa Verlag.

Mag, Wolfgang 1990. Grundzüge der Entscheidungstheorie. München: Vahlen.

Nord, Christiane 1989. Loyalität statt Treue: Vorschläge $\mathrm{zu}$ einer funktionalen Übersetzungstypologie. Lebende Sprachen 34(3): 100-105.

- 2001. Translating as a Purposeful Activity. Functionalist Approaches Explained. Manchester: St. Jerome Publishing.

Pfohl, Hans-Christian; Braun, Günther E. 1981. Entscheidungstheorie. Normative und deskriptive Grundlagen des Entscheidens. Landsberg am Lech: Verlag moderne industrie.

Turk, Horst 1996. Kulturkonflikte im Spiegel der Literatur? Arcadia: Zeitschrift für Allgemeine und Vergleichende Literaturwissenschaft 31: 4-26.

Vermeer, Hans J. 1986. Übersetzen als kultureller Transfer. In: Snell-Hornby, Mary (ed.), Übersetzungswissenschaft - eine Neuorientierung. Zur Integrierung von Theorie und Praxis. Tübingen: Francke, 30-53.

- 1989. Skopos und Translationsauftrag. Heidelberg: Institut für Übersetzen und Dolmetschen der Universität Heidelberg.

Welsch, Wolfgang 1999. Transculturality - the puzzling form of cultures today. In: Featherstone, Mike; Lash, Scott (eds.), Spaces of Culture: City, Nation, World. London: Sage, 194-213.

Wilss, Wolfram 2005. Übersetzen als wissensbasierter Textverarbeitungsprozess. In: Zybatow, Lew N. (ed.), Translatologie - neue Ideen und Ansätze. Frankfurt am Main: Peter Lang, 5-22. 


\section{Конфликтные решения при межкультурном переводе}

Переводчик как чиен определенной кумьтуры (как правило культуры языка перевода) принимает переводческие решения исходя из перспективы своей культуры, причем сами решения мотивированы чужой (исходной) культурой. РазАичие культур может вызвать конфликтные решения, когАа переводчик Аолжен иАти на компромисс межАу разными участниками процесса - автором исходного текста, аАресатами перевода и самим собой. ПоА конфликтными решениями имеются в виАу внутренние сомнения переводчика в связи с его целями, интересами, ценностями, методами перевода или с их послеАствиями, вызванными разными культурными фонами исходного текста и текста перевода. Конфмиктные решения ощущаются, как правияо, как субъективные проблемы перевода. Переводчик должен уметь подходить к тексту с разных точек зрения. Конфликты возникают, когда перспективы разных культур, которые переводчик старается согласовать в своем переводе, в принципе несовместимы без ущерба дия одной из этих кумьтур. Аействие на перекрестке Авух культур и учитывание интересов всех участников крайне осложняют переводческие решения.

\section{Otsustuskonfliktid kultuuridevahelises tõlkimises}

Tõlkija kui teatud kultuuri (reeglina sihtkeelse kultuuri) liige langetab tõlkealaseid otsuseid oma kultuuri perspektiivist, kusjuures otsused on motiveeritud (võõrast) lähtekultuurist. Kultuuride erinevus võib põhjustada otsustuskonflikte, mille korral tõlkija peab jõudma kompromissile erinevate osapooltega - nii lähteteksti autori, sihtadressaatide kui ka iseendaga. Artiklis analüüsitakse kultuurierinevustest tingitud otsustuskonflikte tõlkeprotsessis. Kultuurist tingitud otsustuskonfliktide all peetakse silmas tõlkija sisemisi kahtlusi seoses tema eesmärkide, huvide, väärtuste, veendumuste, tõlkemeetodite või nende tagajärgedega, mis on tingitud lähteteksti ja sihtteksti erinevast kultuuritaustast. Otsustuskonflikte tajutakse reeglina subjektiivsete tõlkeprobleemidena. Tõlkija peab olema suuteline lähenema tekstile erinevatest perspektiividest. Konfliktid tekivad siis, kui kahe kultuuri perspektiivid, mida tõlkija üritab tõlke abil kokku viia, ei ole ühendatavad, ilma et mõni protsessi osapooltest kannataks. Tegutsemine kahe kultuuri lõikepunktis, arvestamine mitme osapoole huvidega muudab tõlkealased otsused äärmiselt keeruliseks. 